\title{
NM and Paclobutrazol Control Grapevine Suckers: Vine Performance and Fruit Tissue Residues
}

\author{
Andrew G. Reynolds', A.C. Cottre11 ${ }^{2}$, D.A. Wardle ${ }^{3}$, and \\ A.P. Gaunce ${ }^{4}$ \\ Agriculture Canada Research Station, Summerland, B.C. VOH lZ0, \\ Canada
}

Additional index words. 'Okanagan Riesling', growth regulators, growth retardants, Vitis

Abstract. 'Okanagan Riesling' (Vitis spp. parentage unknown) vine trunks treated in 1984 with three levels of $\mathrm{NM}\left(0,10,000\right.$, and $\left.20,000 \mathrm{mg} \cdot \mathrm{liter}^{-1}\right)$ and three levels of paclobutrazol $\left(\mathrm{PB} ; \mathbf{0}, \mathbf{2 5 0}\right.$, and $500 \mathrm{mg} \cdot \mathrm{liter}^{-1}$, in white latex paint were subjected to a reapplication in June 1987 at the same rates of NAA and at 0,1000 , and $2000 \mathrm{mg}$ $\mathrm{PB} /$ liter. Linear reductions in suckers per vine were observed with increasing NAA concentration but not $\mathrm{PB}$. Yield and clusters per vine were reduced by $\mathrm{PB}$ in the season following retreatment (1988), while berry weight was increased by NAA in 1987. Titratable acidity was increased by NAA in 1988, and pH was highest that season with PB at $1000 \mathrm{mg} \cdot \operatorname{liter}^{-1}$ No PB was detected in fruit tissue in 1987 , but NAA levels of 2.4 and $2.0 \mu \mathrm{g} \cdot \mathrm{kg}^{-1}$ were detected in clusters sampled from the 10,000- and 20,000 mg.liter ${ }^{-1}$ treatments, respectively. Chemical names used: l-naphthaleneacetic acid (NAA); B-1[(4-chlorophenyl)methy]- $\alpha$-1 (1,l-dimethylethyl)-1H-1,2,4-triazole-l-ethano1 (paclobutrazol).

Manual suckering of grapevine trunks is a costly and laborious procedure. Success with chemical control of trunk suckers has been demonstrated by several workers through the use of NAA (Ahmedullah and Wolfe, 1982; Eynard et al., 1986; Morris and Cawthon, 1981), paclobutrazol (PB) (Reynolds, 1988a, 1989), and nontranslocatable herbicides (Leppert et al., 1985). Reynolds (1988a, 1989) also found that trunk-applied NAA and PB increased yield, several yield components, ${ }^{\circ}$ Brix, and titratable acidity, although the effects of PB were shorter lived.

Received for publication 22 Jan. 1991. Summerland Research Station contribution no. 772. The gifts of paclobutrazol from Bill Moons of Chipman, Inc., and of dichlobutrazol from ICI Americas, Inc., are gratefully acknowledged. The cost of publishing this paper was defrayed in part by the payment of page charges. Under postal regulations, this paper therefore must be hereby marked advertisement solely to indicate this fact.

'Research Scientist, Pomology and Viticulture Section.

${ }^{2}$ Research Assistant, Soil Science and Agricultural Engineering Section.

${ }^{3}$ Research Assistant, Pomology and Viticulture Section.

${ }^{4}$ Research Scientist, Soil Science and Agricultural Engineering Section.
Although plans to register PB on fruit crops in North America have been abandoned by the producer (W. Moons, Chipman Inc., personal communication), interest still exists for the registration and use of NAA as a sucker control agent for grapes. Registration is contingent on the demonstration of efficacy for its intended purpose, as well as the assurance that residues in fruit tissue fall below established Canadian tolerances, currently at $100 \mu \mathrm{g} \cdot \mathrm{kg}^{-1}(0.1 \mathrm{ppm})(\mathrm{G}$. Orriss, personal communication). The purpose of this investigation was to assess the effects of a reapplication of NAA and $\mathrm{PB}$ to trunks of 'Okanagan Riesling' vines in terms of sucker control, yield, fruit composition, and chemical residues in fruit tissue.

This experiment was superimposed on an existing trial described previously (Reynolds, 1988a). Fourteen-year-old 'Okanagan Riesling' vines, whose trunks were originally treated in May 1984 with NAA at 0, 10,000 , or $20,000 \mathrm{mg} \cdot \mathrm{liter}^{-1}$ or PB at 0 , 250 , or $500 \mathrm{mg} \cdot \mathrm{liter}^{-1}$, were, respectively, subjected to a reapplication of NAA at the same levels or PB at 0,1000 , or 2000 mg.liter ${ }^{-1}$. Application date was 9 July 1987. All experimental procedures and cultural practices remained consistent with those of previous seasons (Reynolds, 1988a). The experiment was designed as a randomized complete block with six treatments (three rates each of two chemicals), eight blocks, and three-vine treatment replicates.

Two clusters per treatment replicate were collected at harvest in 1987 and stored at $-40 \mathrm{C}$ for residue analysis. Harvest dates were 10 Sept. 1987 and 20 Sept. 1988. Vines were removed in Mar. 1989, thus preventing the collection of data for more than two seasons.

The method for NAA extraction and quantitation was adapted from Shiga et al. (1976) and Cochrane and Lanouette (1979). Frozen berries $(50 \mathrm{~g})$ were removed from their rachises and blended with $100 \mathrm{ml}$ of acetone containing $5901.8 \mathrm{M} \mathrm{H}_{2} \mathrm{SO}_{4}$ and a disk of filter paper. Following filtration, the residue was reextracted with the acetone solution (100 $\mathrm{ml})$ and filtered. The combined filtrates were evaporated to $\approx: 20 \mathrm{ml}$, adjusted to $\mathrm{pH}>8$ with $\mathrm{NaOH}$, and filtered. The basic filtrate was washed with two $25-\mathrm{ml}$ aliquots of dichloromethane and acidified to $\mathrm{pH}<2$ with $\mathrm{H}_{2} \mathrm{SO}_{4}$. It was then extracted with 50-, 25-, and 25-ml sequential additions of dichloromethane. The extract was passed through anhydrous $\mathrm{Na}_{2} \mathrm{SO}_{4}$, evaporated, and redissolved in $2.0 \mathrm{ml}$ of $50 \%$ acetonitrile. The NAA was analyzed by high-performance liquid chromatography (model 510; Waters, Milford, Mass.) and detected with a Kratos FS970 fluorimetric detector (excitation $220 \mathrm{~nm}$, emission >310 nm; Kratos Analytical Instruments, Ramsay, N.J.). The mobile phase $\left(1 \mathrm{ml} \cdot \mathrm{min}^{-1}\right)$ employed a gradient of $32 \%$ to $80 \%$ acetonitrile in phosphate buffer $(7 \mathrm{mg}$ $\mathrm{Na} \mathrm{H}_{2} \mathrm{P} \mathrm{O}_{4}$ /liter adjusted to $\mathrm{pH} 2.0$ with $\mathrm{H}_{3} \mathrm{PO}_{4}$ ), and the column was a $15 \mathrm{~cm} \times 3.9$ mm Novapac C18 (Waters).

Table 1. Effect of trunk-applied NAA and paclobutrazol on growth components of 'Okanagan Riesling' grapevines, 1987 and 1988.

\begin{tabular}{lcccc}
\hline & \multicolumn{3}{c}{ Suckers/vine } \\
\cline { 2 - 5 } \cline { 4 - 5 } Chemical & May & & May & \multicolumn{2}{c}{ September } \\
\cline { 3 - 5 } NAA $\left(\mathrm{mg} \cdot\right.$ liter $\left.^{-1}\right)$ & & & \\
0 & 13.1 & 14.1 & 1.9 \\
10,000 & 10.0 & 5.8 & 0.8 \\
20,000 & 7.6 & 2.7 & 0.3 \\
Significance & $\mathrm{L}^{* *}$ & $\mathrm{~L}^{* * *}$ & $\mathrm{~L}^{* *}$ \\
Paclobutrazol & $\left(\mathrm{mg} \cdot\right.$ liter $\left.^{-1}\right)$ & & \\
0 & 13.0 & 12.5 & 2.6 \\
1,000 & 11.6 & 10.9 & 2.2 \\
2,000 & 10.5 & 9.8 & 1.1 \\
Significance & NS & NS & NS \\
\hline
\end{tabular}

${ }^{\mathrm{z}} \mathrm{L}=$ linear trend.

NS,**,***Nonsignificant or significant at $P<0.01$ or 0.001 , respectively. 
Table 2. Effect of trunk-applied paclobutrazol on yield components of 'Okanagan Riesling' grapevines, 1987 and 1988.

\begin{tabular}{|c|c|c|c|c|c|c|c|c|c|c|}
\hline \multirow[b]{2}{*}{ Chemical } & \multicolumn{2}{|c|}{$\begin{array}{c}\text { Yield } \\
\left(\mathrm{t} \cdot \mathrm{ha}^{-1}\right)\end{array}$} & \multicolumn{2}{|c|}{ Clusters/vine } & \multicolumn{2}{|c|}{$\begin{array}{c}\text { Cluster wt } \\
\text { (g) }\end{array}$} & \multicolumn{2}{|c|}{$\begin{array}{c}\text { Berries/ } \\
\text { cluster }\end{array}$} & \multicolumn{2}{|c|}{$\begin{array}{c}\text { Berry wt } \\
(\mathrm{g})\end{array}$} \\
\hline & 1987 & 1988 & 1987 & 1988 & 1987 & 1988 & 1987 & 1988 & 1987 & 1988 \\
\hline \multicolumn{11}{|c|}{ Paclobutrazol (mg-liter $\left.{ }^{-1}\right)$} \\
\hline 0 & 11.5 & 17.6 & 81.0 & 134.8 & 105.9 & 96.7 & 61.9 & 52.8 & 1.71 & 1.82 \\
\hline 1000 & 11.0 & 13.4 & 82.7 & 107.3 & 99.4 & 88.8 & 58.2 & 52.0 & 1.70 & 1.70 \\
\hline 2000 & 11.1 & 13.8 & 80.0 & 111.1 & 104.5 & 90.5 & 61.0 & 52.1 & 1.71 & 1.70 \\
\hline Significance $^{z}$ & NS & $\mathrm{L}^{*}$ & NS & $\mathrm{L}^{* *}$ & NS & NS & NS & NS & NS & NS \\
\hline
\end{tabular}

${ }^{2} \mathrm{~L}=$ linear trend.

NS,*,**Nonsignificant or significant at $P<0.05$ or 0.01 , respectively.

The method for PB extraction from grape tissue and its subsequent quantification by gas chromatography-mass spectrometry (GCMS) was adapted from Reed (1988) and Stably and Buchanan (1986). Frozen berries (25 g) were removed from their rachises, blended with $40 \mathrm{ml}$ of $80 \%$ methanol, and filtered along with a $10-\mathrm{ml}$ rinse. The residue was reextracted ( $40 \mathrm{ml}$ plus $20 \mathrm{ml}$ rinse) and the combined filtrate, diluted with $400 \mathrm{ml}$ of water and $5 \mathrm{ml} 16 \% \mathrm{NaCl}$, was extracted with 75 $\mathrm{ml}$ of dichloromethane. The combined extract was passed through $\mathrm{Na}_{2} \mathrm{SO}_{4}$ and evaporated. The residue, including internal standard (dichlobutrazol), was made up to $1.0 \mathrm{ml}$ for GC-MS analysis. $\mathrm{PB}$ was analyzed using a Hewlett-Packard 5890A GC (Hewlett-Packard, Mississauga, Ont., Canada) with a 5970 mass selective detector and a $25 \mathrm{~m} \times 0.32 \mathrm{~mm}$ i.d. HP-17 capillary column. Selected ion monitoring was used for quantitation (mass : charge ratio $=125$, 167,236, and 238 for PB and 270, 272, and 274 for dichlobutrazol).

Data were analyzed by the SAS statistical package (SAS Institute, Cary, N. C.) using the General Linear Models procedure. Linear and quadratic trends were ascertained through the use of single degree-of-freedom contrasts.

Trunk sucker number per vine varied inversely with NAA concentration (Table 1), as reported previously (Reynolds, 1988a). PB tended to reduce trunk suckering as well, but the effect of PB was not significant. Reynolds (1988a) reported reductions in sucker count resulting from applications of $\mathrm{PB}$ at 250 to $500 \mathrm{mg} \cdot \mathrm{liter}^{-1}$; thus, it was unexpected that concentrations four times higher did not elicit a similar or greater response. There was no effect of NAA or PB on weight of cane prunings (range 0.68 to 0.83 and 0.75 to $0.89 \mathrm{~kg} / \mathrm{vine}$, respectively). Increases in cane pruning weight proportional to NAA concentration were previously demonstrated (Reynolds, 1988a). Ahmedullah and Wolfe (1982), Eynard et al. (1986), and Morris and Cawthon (1981) reported no effects of NAA on cane pruning weights of 'Sauvignon blanc', 'Merlot', and 'Concord', respectively.

NAA had no significant effects on yield or yield components, other than a linear increase in berry weight in 1987 associated with increasing NAA level $(1.69,1.74$, and 1.78 for $0,10,000$, and $20,000 \mathrm{mg} \cdot$ liter $^{-1}$, respectively). PB reduced yield and clusters per vine in 1988 (Table 2). Yield and yield components for NAA-treated vines were similar to those for vines treated with $\mathrm{PB}$. Reynolds (1988a) demonstrated linear increases in several yield components with increasing NAA level, but other workers (Ahmedullah and Wolfe, 1982; Eynard et al., 1986; Morris and Cawthon, 1981) reported no impact of NAA on yield or yield components. Trunk-applied PB (Reynolds, 1988a) or foliar-applied PB (Reynolds, 1988b) may increase berry size if applied at levels $<750 \mathrm{mg} \cdot$ liter $^{-1}$

Effects of NAA and PB on fruit composition were mostly nonsignificant, other than a linear increase in titratable acidity with increasing NAA level in 1988 (8.9, 9.7, and $9.6 \mathrm{~g} \cdot$ liter $^{-1}$ for $0,10,000$, and 20,000 $\mathrm{mg} \cdot$ liter $^{-1}$ respectively) and an elevation in $\mathrm{pH}$ with $\mathrm{PB}$ at $1000 \mathrm{mg} \cdot$ liter $^{-1}$ that same year $(3.14,3.20$, and 3.14 at 0,1000 , and $2000 \mathrm{mg} \cdot$ liter $^{-1}$ respectively). Trunk-applied NAA was reported to enhance sugar accumulation and titratable acidity in 'Okanagan Riesling' (Reynolds, 1988a), although others (Ahmedullah and Wolfe, 1982; Eynard et al., 1986; Morris and Cawthon, 1981) found no impact of NAA on fruit composition. Fruit maturity was advanced in 'Okanagan Riesling' by trunk-applied PB (Reynolds, 1988a) and by foliar application of PB on 'Riesling' (Reynolds, 1988b) and Gewürztraminer vines (Reynolds and Wardle, 1989).

Levels of NAA in fruit tissue averaged 2.4 \pm 2.7 and $2.0 \pm 1.1 \mu \mathrm{g} \cdot \mathrm{kg}^{-1}(\mathrm{ppb})$ for the 10,000 and $20,000 \mathrm{mg} \cdot \mathrm{liter}^{-1}$ levels, respectively. A mean of $0.07 \mu \mathrm{g} \cdot \mathrm{kg}^{-1}$ was detected at the 0 -mg.liter ${ }^{-1}$ level, but this was very close to the $0.02-\mu \mathrm{g} \cdot \mathrm{kg}^{-1}$ detection limit and was likely an artifact. Mean PB levels were all below the $10-\mu \mathrm{g} \cdot \mathrm{kg}^{-1}$ detection limit.

The negligible levels of PB detected in the fruit tissue may have been due to lack of uptake and migration from point of application, exclusive movement in the transpiration stream (Sterrett, 1985), or metabolism within the plant. Ahmedullah et al. (1986) enhanced apparent uptake of this chemical through stripping the bark on the vine trunk and adding dimethylsulfoxide (DMSO) to the application mixture. Although the outer bark was removed immediately before application of PB and NAA in our study, the addition of DMSO might have improved uptake and efficacy.

NAA was detected in small amounts in the fruit, suggesting either direct movement into the fruit via the transpiration stream or retranslocation from the leaves. However, these amounts detected were well below the 100$\mu \mathrm{g} \cdot \mathrm{kg}^{-1}$ tolerance established by Health and Welfare Canada. Although its impact on yield and fruit composition in this study was small, previous significant influence of NAA on yield, yield components, and fruit composition (Reynolds, 1988a) may be attributable to similar movement throughout the vine and into the fruit. Reduction in competition between vegetative growth and berry development could conceivably result in enhanced berry size and accelerated fruit maturity.

The potential for $\mathrm{PB}$ as a sucker control agent in grapes appears low in view of its poor performance in this trial and its shortlived efficacy in previous experiments (Reynolds, 1988a). NAA, however, continues to show promise in this regard, with the possible added benefit of producing larger berries.

\section{Literature Cited}

Ahmedullah, M., A. Kawakami, C.R. Sandidge, III, and R.L. Wample. 1986. Effect of paclobutrazol on the vegetative growth, yield, quality, and winterhardiness of buds of 'Concord' grape. HortScience 21:273-274.

Ahmedullah, M. and W.H. Wolfe. 1982. control of sucker growth on Vitis vinifera L. cultivar Sauvignon blanc with naphthaleneacetic acid. Amer. J. Enol. Viticult. 33:198-200.

Cochrane, W.P. and M. Lanouette. 1979. High pressure liquid chromatographic determination of naphthaleneacetic acid residues in apples. J. Assn. Offic. Anal. Chem. 62:100-106.

Eynard, I., G. Gay, R. Vallania, P. Occelli, R. Botta, M. Dolci, and A. Martini. 1986. Control of sucker growth on Vitis vinifera cv. Merlot with NAA derivatives. Vitis 25:169-177.

Leppert, B., G. Chaler, and J.-C. Vitiello. 1985. $8 \mu$, Sitevi. Causerie technique sur les techniques et matériels d'epamprage de la vigne. Prog. Agr. Viticult. 102:21-22.

Morris, J.R. and D.L. Cawthon. 1981. Control of trunk shoots on 'Concord' grapevines (Vitis labrusca L.) with naphthaleneacetic acid. Hort Science 16:321-322.

Reed, A.N. 1988. Quantitation of triazole and pyrimidine plant growth retardants. J. Chromatography 438:393-400.

Reynolds, A.G. 1988a. Effectiveness of NAA and paclobutrazol for control of regrowth of trunk suckers on 'Okanagan Riesling' grapevines. J. Amer. Soc. Hort. Sci. 113:484-488.

Reynolds, A.G. 1988b. Inhibition of lateral shoot growth in summer-hedged 'Riesling' grapevines by paclobutrazol. HortScience 23:728-730.

Reynolds, A.G. 1989. Control of vegetative growth in Vitis by paclobutrazol-implications for winegrape quality. Acta Hort. 239:235-242.

Reynolds, A.G. and D.A. Wardle. 1989. Impact of various canopy manipulation techniques on growth, yield, fruit composition, and wine quality of Gewürztraminer. Amer. J. Enol. Viticult. 40:121-129.

Shiga, N., O. Matano, and S. Goto. 1976. Microdetermination of 1-naphthaleneacetic acid (in Japanese). J. Pesticide Sci. 1:231-234.

Stably, E.A. and D.A. Buchanan. 1986. Extraction, purification, and quantitation of paclobutrazol from fruit tree tissues. HortScience 21:534535.

Sterrett, J.P. 1985. Paclobutrazol: A promising growth inhibitor for injection into woody plants. J. Amer. Soc. Hort. Sci. 110:4-8. 